\title{
MODEL INTERNALISASI NILAI-NILAI MULTIKULTURAL DALAM PEMBELAJARAN PAI DI SMA NEGERI 1 NGANJUK
}

\author{
Zainal Arifin ${ }^{1)}$, Masyukuri ${ }^{2)}$, Moh. Hanif ${ }^{3)}$ \\ ${ }^{1}$ STAI Miftahul Ula Nganjuk, ${ }^{2,3}$ Universitas Islam Malang, Universitas \\ Islam Malang \\ e-mail: zainalarifin061169@gmail.com, masykuri@unisma.ac.id, \\ muchhanief@gmail.com,
}

\begin{abstract}
ABSTRAK
Kajian ini menggunakan pendekatan kualitatif dengan jenis studi kasus yang mengambil fokus tentang penanaman nilai-nilai multikultural yang terdapat dalam proses pembelajaran di dalam dan luar kelas SMA Negeri 1 Nganjuk. Tujuan penelitian ini adalah mengungkap dan mengembangkan model internalisasi nilai-nilai multikultural yang tumbuh dan berkembang di locus penelitian. Sumber data terkait kajian ini diperoleh menggunakan tehnik wawancara mendalam, observasi partisipatif dan dokumentasi yang diolah menggunakan model interaktif Miles dan huberman. Dari fokus tersebut, dihasilkan sebuah model internalisasi nilai multikultural melaui pengelolaan pembelajaran yang sistematis dan terkoordinasi serta pembiasaan dan pelatihan dalam mengembangkan karakter siswa.
\end{abstract}

Kata kunci : model, internalisasi, nilai multikultural 


\begin{abstract}
This study uses a qualitative approach with a type of case study that focuses on cultivating multicultural values that are contained in the learning process inside and outside the class of SMA Negeri 1 Nganjuk. The purpose of this study is to reveal and develop a model of internalization of multicultural values that grows and develops in the research locus. Sources of data related to this study were obtained using in-depth interview techniques, participatory observation and documentation which were processed using the interactive model of Miles and Huberman. From this focus, a multicultural value internalization model was produced through the management of systematic and coordinated learning as well as habituation and training in developing student character.
\end{abstract}

Keywords: model, internalization, multicultural values

\title{
A. PENDAHULUAN
}

SMAN 1 Nganjuk adalah lembaga pendidikan Islam tingkat menengah yang unggul dan berprestasi di Kota Nganjuk. Lembaga ini dipercaya masyarakat untuk mengelola amanah orang tua dari 990 peserta didik dengan kelas bahasa 57 peserta didik, kelas IPA 634 peserta didik dan kelas IPS 289 peserta didik. ${ }^{1}$ Kerja keras dari 69 guru terdiri 52 PNS dan 18 non PNS serta 18 karyawan telah menempatkan SMAN 1 Nganjuk sejajar dengan sekolah-sekolah unggulan di Indonesia baik di bidang prestasi akademik maupun non akdemik.

Berdasarkan data hasil kegiatan observasi, penelusuran dokumen, serta wawancara dengan beberapa informan, menunjukkan bahwa SMAN 1 Nganjuk yang terletak di Jalan Kasihin HS. No 4 cangkringan Nganjuk ini memiliki "image" sekolah yang guyup atau kompak secara sosial. Hal tersebut tergambarkan dari hubungan antar warga sekolah yang akrab dan

\footnotetext{
${ }^{1}$ Dokumen resmi SMAN 1 Nganjuk thn. 2017
} 
dipenuhi oleh rasa kekeluargaan, mengedepankan kerjasama, kemandirian, sikap saling menghormati, ramah, dan respek terhadap semua warganya yang tercermin dari berbagai interaksi yang ditujukkan oleh warga madrasah baik dalam intern warga sekolah maupun terhadap orang lain, masyarakat di luar SMAN 1 Nganjuk. $^{2}$

Dari investigasi dengan beberapa sumber terkait pembelajaran PAI yang diberlakukan di SMAN 1 Nganjuk, mengarah terhadap muatan nilai pendidikan multikultural. Dengan adanya muatan nilai-nilai tersebut, pembelajaran mata pelajaran Agama Islam di SMAN 1 Nganjuk memiliki posisi yang strategis dalam mewujudkan kesadaran multikultural kepada peserta didik. Selain itu, Mata Pelajaran Pendidikan Agama Islam juga merupakan Mata Pelajaran Pendidikan Agama patut menjadi titik sentral dalam menanamkan nilai-nilai Islam multikultural. ${ }^{3}$

Penanaman nilai-nilai pendidikan multikultural dalam pembentukan karakter selain di proses pembelajaran juga di lakukan di luar kelas. Proses ini dilakukan seperti dalam program pembiasaan dan budaya akademik. Program ini dilakukan oleh Kepala/Waka/guru ketika menyambut kedatangan peserta didik dengan menyalami di depan gerbang. Selain itu program ini juga dilaksanakan saat wali kelas/guru menyalami peserta didik yang akan masuk di depan kelas. ${ }^{4}$

Proses penanaman nilai-nilai multikultural yang terdapat dalam proses pembelajaran di dalam dan luar kelas SMA 1 ngajuk menjadi alasan yang kuat dijadikannya kajian yang lebih mendalam Dan dari latar belakang itulah maka fokus kajian kali ini mengarah pada intenalisasi nilai pendidikan multikultural yang di tanamkan saat proses pembelajaran di SMA 1 Nganjuk.

\footnotetext{
${ }^{2}$ Observasi pada 1 juli 2017

${ }^{3}$ Dokumen standar proses hlm. 62-122

${ }^{4}$ Observasi pada 7 juli 2017
} 


\section{B. METODE PENELITIAN}

Kajian kali ini diarahkn pada latar paradigma interpretif, dengan jenis studi kasus. Jenis ini dipilih dan digunakan untuk mendapatkan temuan substantif sesuai dengan fokus penelitian yang diabstraksikan sebagai temuan formal yang diharapkan dapat membangun suatu teori secara induktif. ${ }^{5}$ Oleh karena itu, penelitian ini dilaksanakan dengan selektif, sebaik mungkin dan bersungguh-sungguh sehingga data dapat terkumpul dengan benar dan relevan serta terjamin keabsahannya.

Data diperoleh dari subyek yang dipilih dengan purposif sampling dan snowball sampling melalui tiga rangkaian tehnik pengumpulan data, yaitu wawancara mendalam, observasi partisipatif dan dokumentasi. Sehingga informan dalam penelitian ini adalah orang-orang yang mengetahui dan ditunjuk serta menunjuk orang lain yang kaya akan sumber data yang dimaksud. ${ }^{6}$

Rangkaian data yang terkumpul tersebut kemudian diolah dan dianalisis menggunakan model pengolahan data interaktif sebagaimana Miles dan huberman kemukakan. ${ }^{7}$ Data juga diolah dan diverifikasi menggunakan tehnik trianggulasi. Trianggulasi menghendaki data untuk dibandingkan antar sumber data, tehnik dan waktu.

\section{TEMUAN PENELITIAN}

Model internalisasi nilai-nilai multikultural dalam proses pembelajaran PAI di SMAN 1 Nganjuk terintegrasikan dalam tiga kegiatan utama, yaitu perencanaan pembelajaran, proses pembelajaran serta evaluasi pembelajaran. Ketiga proses ini merupakan siklus kegiatan yang berjalan tahap demi tahap .

5 Mudjia Rahardjo, Bahan Perkuliahan Metodologi Penelitian Program Doktor Manajemen Pendidikan Islam (Malang: Pascasarjana UIN Maliki, 2010), 35

6 W.Mantja, Etnografi Desain Penelitian Kualitatif dan Manajemen Pendidikan, (Malang; Winaka Media, 2003), 99

M.B. Miles \& huberman A.M. Qualitative Data Analysis (California; Sage Publication, 1994), hlm. 12 
Proses internalisasi nilai Multikultural sebagaimana di atas, selaras dengan permendikbud no. 22 tahun 2016 tentang standar proses pendidikan dasar dan menengah meliputi ; perencanaan pembelajaran, pelaksanaan pembelajaran, dan penilaian pembelajaran. Tiga tahapan tersebut juga sejalan dengan proses internalisasi pembelajaran yang dicanangkan Mulyasa; merencanakan pembelajaran, melaksanakan pembelajaran, dan mengevaluasi pembelajaran. ${ }^{8}$

Kaitannya dengan perencanaan pembelajaran PAI, guru PAI di SMAN 1 Nganjuk telah menyusun perangkat pembelajaran PAI berupa pengembangan silabus dan sistem penilaian PAI, program tahunan PAI, program semester PAI, rencana pelaksanaan pembelajaran PAI, penghitungan hari/minggu efektif PAI dan UKBM (unit kegiatan belajar mandiri). Kegiatan tersebut sesuai dengan apa yang dikemukakan oleh Mujamil Qomar. ${ }^{9}$

Melalui dokumentasi dan wawancara yang peneliti lakukan, diperoleh data bahwa semua guru telah mengembangkan silabus sebagaimana arahan dalam orientasi, mencakup kompetensi inti, kompetensi dasar, indikator, materi pokok, strategi pembelajran, penilaian, alokasi waktu, dan sumber/media yang digunakan dalam penyusunan UKBM (unit kegiatan belajar mandiri).

Sedangkan tahapan-tahaon perencanaan yang dillukan SMA 1, terdapat empat kegiatan. Pertama mengintegrasikan nilai-nilai multikultural ke dalam visi, misi, tujuan dan budaya sekolah. Proses integrasi tersebut tersirat pada indikator visi sekolah pada point b dan $\mathrm{d}$ yaitu "Unggul dalam kegiatan keagamaan, dan budi pekerti; Unggul dalam bidang organisasi dan kepemimpinan". Sedangkan di misi sekolah tersirat "Menumbuhkan semangat penghayatan terhadap ajaran agama yang dianut dan juga potensi dirinya, sehingga menjadi kearifan dalam bertindak". Dalam kegiatan ini, nilai-nilai PAI tidak berdiri sendiri melainkan keterkaiatan antara satu dengan lainnya.

${ }^{8}$ E. Mulyasa. Manajemen berbasis sekolah, konsep, strtegi, dan implementasi, (Bandung; PT. Remaja Rosda Karya, 2002) 39

9 Mujammil Qomar, Strategi Baru Pengelolaan Lembaga Pendidikan Islam :Manajemen Pendidikan Islam (Surabaya: Erlangga, 2007), 160 
Proses kedua dalam perencanaan adalah mengintegrasikan nilai-nilai multikultural dalam kompetensi inti dan kompetensi dasar. Cara ini di maksudkan agar setiap pendidik dapat mengembangkan nilai-nilai multikultural ke dalam program pembelajaran sesuai mata pelajaran yang diampu; setiap pendidik akan mendalami terlebih dahulu materi yang terkait dengan nilainilai multikultural ke dalam rencana pelaksanaan program pembelajaranya sesuai dengan mata pelajaran yang diampu.

Ketiga, mengintegrasikan nilai-nilai multikultural pada berbagai pendekatan yaitu pendekatan integratif dan pembiasaan. Pendekatan integratif meliputi pada materi, metode dan tujuan. nilai-nilai tersebut diintragsikan pada materi-materi pembelajaran pendidikan agama Islam maupun materi umum. Pendekatan pembiasaan, dimaksud mengintegrasikan nilai-nilai multikultural pada program pembiasaan, yaitu ketika peserta didik ketemu pendidik dan tenaga kependidikan berjabat tangan sambil merunduk dan cium tangan, kalau sudah selesai bertajabat tangan peserta didik ambil dua langkah kebelakang sambil merunduk dilanjukan mengucapkan salam.

Proses terakhir dalam perencaan pembelajaran adalah mengintegrasikan nilai-nilai multikultural dalam langkah-langkah pembuatan perangkat pembelajaran dengan memperhatikan berbagai prinsip ; Perbedaan peserta didik baik jenis kelamin, ekonomi, dan latar belakangnya., mendorong keaktipan peserta didik, mengembangkan budaya leterasi, dan penerapan tehnologi dan informasi. Langkah-langkah pembuatan perangkat pembelajaran yang terealisasi dalam bentuk : penghitungan pekan efektif, prota, promes, silabus dan rencana pelaksanaan pembelajaran. Nilai-nilai multikultural terintegrasikan dalam perangkat pembelajaran baik secara eksplisit maupun implisit.

Keempat langkah di atas bila dilihat dari ranah multikulturalisme, integrasi nilai multikultural dilakukan guru ke dalam dokumen seperti silabus, RPP dan UKBM melaui pendekatan aditif dan transformasi. Pendekatan ini selaras dengan James A. Banks yang menawarkan aditif approach and transformation 
approach dalam mengintegrasikan dimensi multikultural ke dalam perencanaan. Selain itu, masih dua pendekatan lagi yang tidak digunakan pihak sekolah dalam integrasi dimensi multikultural, yaitu the contributions approach and the sosial action approach. ${ }^{10}$

Setelah proses perencanaan pembelajaran, internalisasi juga dilakukan melalui pelaksanaan pembelajaran. Dalam proses pembelajaran diawali dengan internalisasi proses pembelajaran di kelas antara lain ; pendidik memberikan contoh positip pada peserta didik dalam setiap pembelajaran sedang berlangsung baik dalam tutur kata maupun tindakan yang mencerminkan nilai-nilai multikultural; pembelajaran berorientasi pada peserta didik sedangkan guru sebagai fasilitator; pengunaaan metode dan pendekatan bervariasi menyesuaikan dengan tujuan, materi dan nilai-nilai yang dikehendaki; menerapkan model CTL, cooperatif learning (CL) dan menyenangkan (PAKEM).

Selain pembelajaran dalam kelas, internalisasi nilai-nilai multikultural juga dilaksanakan melalui pembelajaran di luar kelas atau ektrakurikuler. Kegiatan ektrakurikuler di SMAN 1 Nganjuk secara garis besar dibedakan menjadi dua; kegiatan keagamaan dan non keagamaan. Kegiatan diluar kelas banyak sekali nilai-nilai multikultural yang terintegrasikan baik secara implisit maupun eksplisit.

Dalam hal ini, guru sebagai aktor atau komunikan dalam internalisasi nilai-nilai Multikultural. Aktor atau komunikan menurut Giddens, bisa disebut sebagai agen. Yakni orang yang mempertahankan suatu pemahaman teoretis yang terus menerus tentang landasan aktivitas mereka. ${ }^{11}$ Sebagai agen nilai multikultural, mereka terlebih dahulu harus memiliki kemampuan untuk mengamalkan nilai-nilai multikultural yang disampaikan.

Dalam ranah pembelajaran, Guru mengembangkan budaya multikultural yang diinternalisasikan kemudian turut membimbing

${ }^{10}$ Ramdhan, T. W. (2020). MULTICULTURAL CURRICULUM DEVELOPMENT MODEL (CASE STUDY OF CURRICULUM PLANNING FOR SMA NEGERI 2 KEDIRI). TARBIYA ISLAMIA: Jurnal Pendidikan dan Keislaman, 9(1), 78-87.

${ }^{11}$ Anthony Giddens, Teori Strukturasi, Dasar-Dasar Pembentukan Struktur Masyarakat, (Yogyakarta:Pustaka Pelajar, 2010), 7. 
murid dalam kegiatan ekstra dengan maksud dan tujuan sinergi intrakurikuler. Langkah guru yang memberikan bimbingan dan dorongan kepada para murid ini dalam perspektif konstruktivisme, dijadikan landasan filosofi pembelajaran kontekstual yaitu bahwa pengetahuan dibangun oleh manusia sedikit demi sedikit, yang hasilnya diperluas melalui konteks yang terbatas. Pengetahuan bukanlah seperangkat fakta-fakta, konsep atau kaidah yang siap untuk diambil dan diingat. Mengingat pengetahuan dibangun dalam pikiran anak melalui asimilasi dan akomodasi. ${ }^{12}$

Keberhasilan proses pembelajaran yang dilakukan dalam internalisasi nilai tidak terlepas karena penilaian proses pembelajaran berjalan dengan baik. proses penilaian tersebut selaras dengan Muhaimin yang beroendapat penilaian tidak hanya difokuskan pada penilaian kognitif semata, akan tetapi harus dilakukan penilaian lebih lanjut kedalam ranah afektif. Dengan kata lain, ranah afektif merupakan titik tumpu penilaian dalam proses internalisasi. $^{13}$

Pada aspek penilaian di SMA 1 Nganjuk, internalisasi dilakukan melalui ranah kognitif dan afektif serta psikomotorik. Penekanan penilaian terdapat pada Ranah Afekti. Ranah ini fsangat diperhatikan dalam nilai-nilai multikultural, seperti kesetaraan, keadilan, keramhan, kesopanan, kejujuran, toleran, solidaritas, empati, kasih sayang, kerjasama dan tanggung jawab.

12 Dirman dan Cicih Juarsih, Teori Belajar dan Prinsip-Prinsip Pembelajar yang Mendidik, Seri Peningkatan Kompetensi Guru dalam rangka Implementasi Standar Proses Pendidikan Siswa, (Jakarta:Rineka Cipta, 2002), 12. lihat juga Ramdhan, T. W. (2019). Model Pengembangan Kurikulum Multikultural. Al-Insyiroh: Jurnal Studi Keislaman, 5(2), 39-53.

\section{${ }^{13}$ Muhaimin, Pengembangan Kurikulum Pendidikan Agama}

Islam, ( Jakarta :RajaGrafindo Persada, 2010), hlm. 53-54 lihat juga Ramdhan, T. W. (2019). Model Pengembangan Kurikulum Multikultural. Al-Insyiroh: Jurnal Studi Keislaman, 5(2), 39-53. 
Dalam pelaksanaannya, penilaian dilakukan dengan dua cara yaitu penilaian autentik dan penilaian control langsung. Penilaian autentik adalah penilaian dalam bentuk lisan dan tulisan yang dilakukan pada akhir pembelajaran, midle semester dan ujian akhir semester yang dimaksudkan untuk mengetahui tingkat kemampuan intelektual Peserta didik. Sedangkan penilaian control langsung adalah penilai yang dimaksudkan untuk mengetahui sikap dan prilaku peserta didik selama mengikuti proses pembelajaran termasuk dalam hal kebiasaan mereka dalam mengimplementasikan nilai-nilai PAI multikultural dan sebagainya.

Akhirnya, model internalisasi nilai-nilai multikultural dalam proses pembelajaran PAI di SMAN 1 Nganjuk secara garis besar dilakukan melalui tiga tahapan : 1). Perencanaan pembelajaran (perangkat pembelajaran), 2). Pelaksanaan pembelajaran, meliputi kegiatan dalam dan luar kelas (ektrakurikuler). 3). Penilaian pembelajaran, meliputi tiga ranah ; kognitif, afektip dan psikomotorik dengan jenis penilaian outentik dan kontrol langsung.

Ramgkaian proses internalisasi yang dimulai dari perencanaan, pembelajaran dan penilaian yang dilakukan di SMA 1 Nganjuk, merupakan model holistik-integratif, yakni mengintegrasikan nilai-nilai kedalam perencanaan, pelaksanaan, dan penilaian pembelajaran. Model ini memperkuat teori pendidikan karakter Thomas Lickona yang memberikan penekanan kepada proses memaksimalkan moral knowing, moral feeling, dan moral act.

Untuk memperjelas model internalisasi nilai-nilai multikultural dalam proses pembelajaran dapat digambarkan sebagai berikut: 


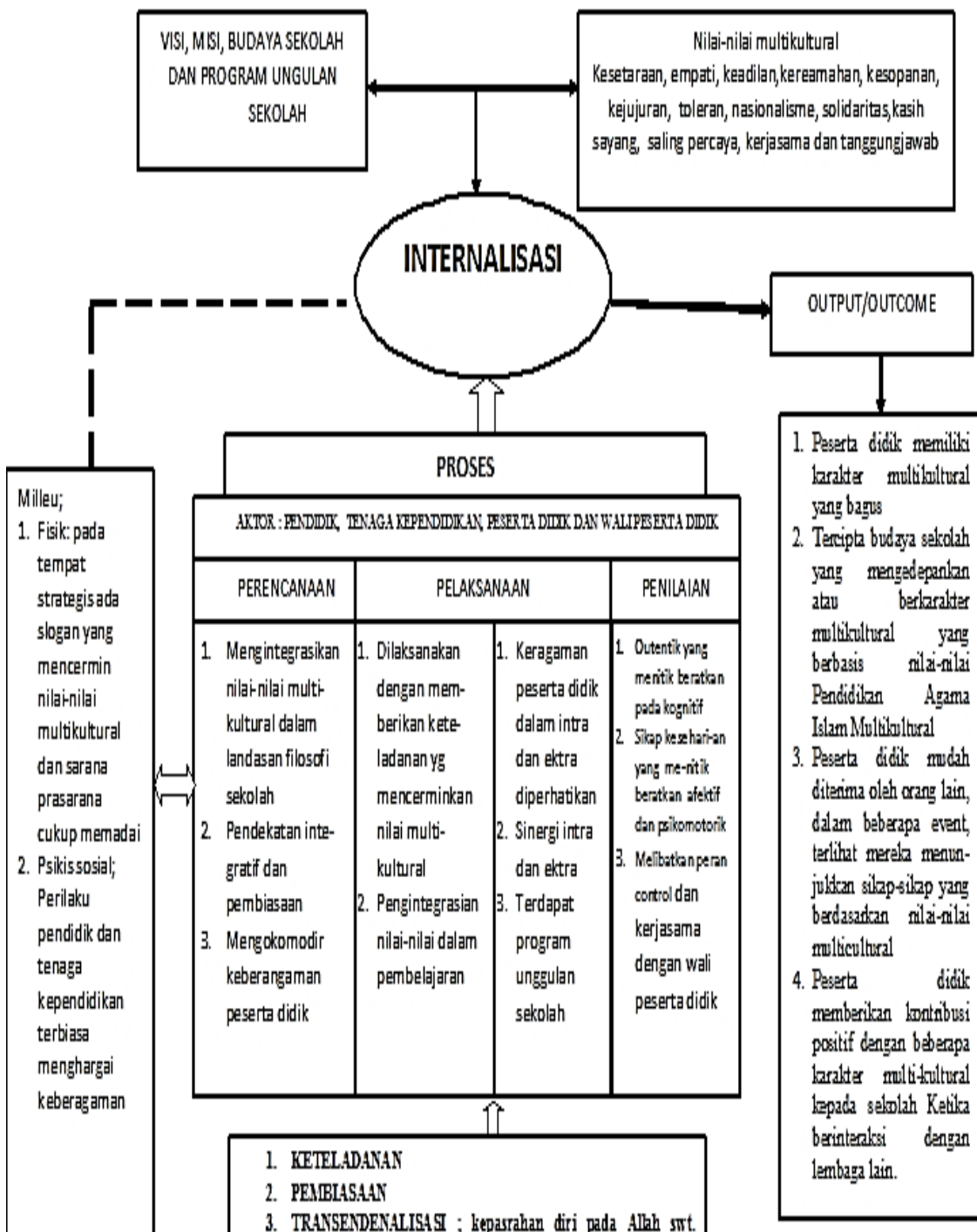

Gambar 1 Model internalisasi nilai multikultural di SMA 1 Nganjuk

\section{KESIMPULAN.}

Model internalisasi nilai-nilai PAI multikultural dalam pembelajaran menggunakan model holistik-integratif, dengan cara mengintegrasikan nilai-nilai PAI multikultural ke dalam perencanaan pembelajaran, pelaksanaan pembelajaran, dan 
penilaian pembelajaran. Model internalisasi nilai multikultural seperti ini menguatkan dan melengkapi teori dari Thomas Likona dan muhaimin. Temuan dilapangan yang melengkapi teori tersebut adalah adanya penambahan, keteladanan, dan pembiasaan, serta transendentalisasi; (kepasrahan kepada Allah swt.)

Guru PAI melakukan pembelajaran yang bagus dimulai dari perencanaan, pengorganisasian, pelaksanaan, sampai evaluasi. Selain itu pula, Guru PAI menggunakan komunikasi yang baik untuk mensinergikan internalisasi yang dilakukan melalui kegiatan pembelajaran dengan beberapa pihak dan juga dengan berbagai kegiatan yang ada. Komunikasi dengan guru mata pelajaran lain diperlukan untuk mengasah kebiasaan murid dalam mempraktekkan nilai multikultural. Sinergi antara intrakurikuler dan ekstrakurikuler bertujuan membiasakan dan membudayakan nilai-nilai Pendidikan Agama Islam Multikultural dalam lingkungan sekolah.

\section{DAFTAR PUSTAKA}

Dirman dan Juarsih, Cicih, 2002, Teori Belajar dan Prinsip-Prinsip Pembelajar yang Mendidik, Seri Peningkatan Kompetensi Guru dalam rangka Implementasi Standar Proses Pendidikan Siswa, Jakarta:Rineka Cipta.

Giddens, Anthony, 2010, Teori Strukturasi, Dasar-Dasar Pembentukan Struktur Masyarakat, Yogyakarta:Pustaka Pelajar

Junaidi, J. (2018). Model Pendidikan Multikultural. Al-Insyiroh: Jurnal Studi Keislaman, 2(1), 57-72.

Mantja, W, 2013, Etnografi Desain Penelitian Kualitatif dan Manajemen Pendidikan, Malang; Winaka Media

Miles, M.B. \& Huberman, A.M, 1994, Qualitative Data Analysis California; Sage Publication

Muhaimin, 2010, Pengembangan Kurikulum Pendidikan Agama Islam, Jakarta : Raja Grafindo Persada

Mulyasa,E, 2002. Manajemen berbasis sekolah, konsep, strtegi, dan implementasi, Bandung; PT. Remaja Rosda Karya, 2002

Qomar, Mujammil, Strategi Baru Pengelolaan Lembaga Pendidikan Islam :Manajemen Pendidikan Islam (Surabaya: Erlangga, 2007), 160 
Rahardjo, Mudjia, 2010, Bahan Perkuliahan Metodologi Penelitian Program Doktor Manajemen Pendidikan Islam Malang: Pascasarjana UIN Maliki

Ramdhan, T. W. (2018). Dimensi Moderasi Islam. Al-Insyiroh: Jurnal Studi Keislaman, 2(2), 29-48.

Ramdhan, T. W. (2019). Model Pengembangan Kurikulum Multikultural. AlInsyiroh: Jurnal Studi Keislaman, 5(2), 39-53.

Ramdhan, T. W. (2020). Multicultural Curriculum Development Model (Case Study of Curriculum Planning for SMA Negeri 2 Kediri). Tarbiya Islamia: Jurnal Pendidikan dan Keislaman, 9(1), 78-87 